\title{
In vivo and carcass characteristics of goats and sheep sold for slaughter in Ceará State
}

\author{
Características in vivo e de carcaça de caprinos e ovinos \\ comercializados para abate no estado do Ceará
}

\author{
Ítalo Araújo Albuquerque ${ }^{1 *}$; Arturo Bernardo Selaive Villarroel ${ }^{2}$; \\ Elzânia Sales Pereira²; Marcílio Costa Teixeira3 ${ }^{3}$; Elisabeth Mary Cunha da Silva ${ }^{4}$; \\ Patrícia Guimarães Pimentel2; Sônia Maria Pinheiro de Oliveira²
}

\begin{abstract}
This study was conducted to evaluate the in vivo and carcass characteristics of goats and sheep sold for slaughter, which originated from different regions of Ceará State, Brazil. Thirty-six (36) mixedbreed, uncastrated male animals (18 goats and 18 sheep), acquired from street markets, which were raised in an extensive production system from the regions of Quixadá, Sobral, and Tauá, were used in this experiment. Before slaughter, the animals were weighed, and body measurements were taken and the body condition score was assessed. Post-slaughter, the carcasses were weighed, morphometric measurements were obtained, and the commercial cuts were weighed and their yields were calculated. The mean in vivo body weight was $23.83 \pm 3.76 \mathrm{~kg}$ for the goats and $25.22 \pm 5.25 \mathrm{~kg}$ for the sheep; the body condition score was close to 2 , and the mean age was 12 months, with no differences between the species. No differences were found between species and origin for the weights and yields of carcass or for chilling loss. The carcass conformation values were considered poor, and the fat cover was classified as too lean, with the goat carcasses considered superior to the sheep carcasses in these respects. The sheep had higher values for loin-eye area, subcutaneous fat thickness, and weight and proportion of leg than the goats. Mixed-breed goats and sheep reared in extensive systems in Ceará State and sold in street markets in the capital, irrespective of their origin, reach their slaughter weight at an advanced age and with a lean body condition, resulting in carcasses of a low quality, with a low muscle content and poor fat cover. In the extensive conditions of the state of Ceará, animals of the ovine species have a greater ability for meat production than caprine species.
\end{abstract}

Key words: Body condition score, body measurements, commercial cuts, extensive production system, meat, slaughter weight

\section{Resumo}

O trabalho foi realizado com o objetivo de avaliar as características in vivo e de carcaça de caprinos e ovinos comercializados para abate, oriundos de diferentes regiões do estado do Ceará. Foram avaliados 36 animais sem raça definida (SRD), 18 caprinos e 18 ovinos, machos não castrados, adquiridos em feiras livres, criados em sistema extensivo de produção, advindos das regiões de Quixadá, Sobral e

\footnotetext{
${ }^{1}$ Discente do Programa de Doutorado Integrado em Zootecnia, Universidade Federal do Ceará, UFC, Fortaleza, CE, Brasil. E-mail: italoaral@yahoo.com.br

2 Profs. Drs., Dept ${ }^{\circ}$ de Zootecnia, UFC, Fortaleza, CE, Brasil. E-mail: selaive@ufc.br; elzania@hotmail.com; pgpimentel@ hotmail.com; soniace@ufc.br

3 Prof., Instituto Federal de Educação, Ciência e Tecnologia do Ceará, IFCE, Umirim, CE, Brasil. E-mail: marcilioct@hotmail.com

${ }^{4}$ Prof $^{\mathrm{a}}$, Dept ${ }^{\mathrm{o}}$ de Engenharia de Alimentos, UFC, Fortaleza, CE, Brasil. E-mail: elisabeth.cunha@gmail.com

* Author for correspondence
} 
Tauá. Antes do abate os animais foram pesados, sendo realizadas as mensurações zoométricas e de escore corporal e, pós-abate, foram realizadas as pesagens e mensurações morfométricas das carcaças, assim como as pesagens e rendimentos dos cortes comerciais. In vivo, o peso corporal (PVA) médio foi de 23,83 $\pm 3,76 \mathrm{~kg}$ para os caprinos e 25,22 $\pm 5,25 \mathrm{~kg}$ para os ovinos, escore corporal próximo a 2 e idade média de 12 meses, sem diferença entre as espécies. Nas carcaças, não houve diferença entre as espécies e procedências para pesos e rendimentos de carcaça e perdas por resfriamento. As conformações das carcaças foram avaliadas como ruins e a cobertura de gordura avaliada como muito magra, com superioridade dos valores das carcaças caprinas em relação às ovinas nestes aspectos. Os ovinos apresentaram maiores valores de área de olho de lombo, espessura de gordura subcutânea e maior peso e proporção de perna que os caprinos. Caprinos e ovinos sem raça definida, criados em sistema extensivo no estado do Ceará e comercializados nas feiras livres na capital, independente da região de origem, alcançam o peso de abate com idade avançada e condição corporal magra, resultando em carcaças de qualidade inferior, pouco musculosas e mal acabadas. Nas condições extensivas de criação no estado do Ceará animais da espécie ovina apresentam maior habilidade em produzir carne que a caprina.

Palavras-chave: Carne, cortes comerciais, escore corporal, medidas zoométricas, peso ao abate, sistema extensivo de produção

\section{Introduction}

The Brazilian Northeast is home to $57 \%$ of the national sheep herd, with about 10 million animals in 2011; the state of Ceará has second largest herd of this species in the region, with approximately two million animals (IBGE, 2013). Sheep farming is a potentially promising business, being important as a source of protein foods in underdeveloped and developing regions and has thus been actively persued in recent decades (LEITE; VASCONCELOS, 2000).

Goats are present in considerable numbers in the Brazilian northeast region and account for approximately $81 \%$ of the national herd; this reached 8.4 million animals in 2011, with approximately one million of these in Ceará State (IBGE, 2013). This species is recognized for its socioeconomic importance regarding milk and meat production, and constitutes an important source of low-cost protein, in addition to being a source of income to the population of the region (SILVA; ARAÚJO, 2000). Producing goats in semi-arid regions is a feasible activity due to their resistance to bad climate conditions especially by native animals of mixed breeds, and their crossbreeds with other breeds with regard to heat tolerance and use of lowquality forage, which occurs mainly during drought periods (OLIVEIRA et al., 2006; SOUZA et al., 2008).

However, goat and sheep farming in the Northeast is characterized by its low productivity, which is usually related to the extensive productive system, the most commonly adopted system in the region (GUIMARÃES FILHO et al., 2000; COSTA et al., 2008), because the irregular rainfall and periodic droughts impose severe restrictions to the supply of forage, and consequently to the availability of nutrients (ARAÚJO FILHO; SILVA, 2000). Likewise, disorderly breeing has contributed to the appearance of a high percentage of mixedbreed animals, which are rustic, but less-productive (MARTINS JÚNIOR et al., 2007). This situation means that animals only reach their slaughter weight at an advanced age and with carcasses of low quality, resulting in seasonal production and an irregular supply of meat of these species in quantity and quality within the region.

To improve the production and performance of the small ruminants reared in the Brazilian Northeast, several techniques are known and have been proposed, ranging from simple measures of food preservation for the dry season, to the use of biotechnologies for reproduction and the use of improved breeds, aiming at a greater modernization 
of production (SILVA SOBRINHO, 2001b; NUNES et al., 2007; SILVA et al., 2010). Nevertheless, before taking action to promote improvements, the current situation of the market should be diagnosed concerning the animals sold for slaughter from the most commonly used production systems for the rearing of goats and sheep in the region. In this way, the product can be characterized, and subsequently, a strategic plan can be proposed for the maintenance of, or alteration to, the current methods of producing goats and sheep in the state.

The objective of this study was therefore to evaluate the in vivo and carcass characteristics of goats and sheep sold for slaughter, originating from different regions of Ceará State, Brazil.

\section{Materials and Methods}

The study was conducted in the Departments of Animal Science and Food Technology of The Federal University of Ceará (UFC), in November and December 2010. A total of 36 animals (18 sheep and 18 goats) that were sold for slaughter in the state of Ceará were used for the experiment. The animals were reared in the conventional system of the region, characterized by its extensive condition, with different animal species sharing the same grazing area, which is dominated by native pasture, and in which some producers perform management techniques of the Caatinga biome, such as thinning and the lowering of pastures (ARAÚJO FILHO et al., 1999; COSTA et al., 2008). In the dry season, producers supplement their animals with available food resources, only for their maintenance (COSTA et al., 2008).

The animals were acquired form street markets in the capital, and they originated from the regions of Ceará state with the largest herds and highest intake of both species: the Sertão Central, the North Region, and the Sertões dos Inhamus, represented by the municipalities of Quixadá, Sobral, and Tauá, respectively. The animals were uncastrated, of a mixed breed, and had a mean age of 12 months. Six animals of each species were used per region.

The methods utilized for animal and carcass measurements were described in Cezar and Sousa (2007). After purchasing the animals, they were transferred to the Sheep and Goat Section of UFC. After a previous solid-deprivation period of 24 $\mathrm{h}$, the animals were fed a liquid diet for $16 \mathrm{~h}$ and were then weighed to determine their live weight at slaughter (SW). Their body condition was also measured by palpating their lumbar region, and was classified into (fractional) scores that ranged from 1 to 5 .

Before the slaughter, the following body measurements were taken with the animals standing on a flat surface: body length (BL) - the distance between the cervicothoracic junction and the base of the tail at the first intercoccygeal joint; forequarter height $(\mathrm{FH})$ - the distance between the region of the withers and the distal end of the forelimbs; hindquarter height $(\mathrm{HH})$ - the distance between the sacral tuberosity and the distal end of the hind limbs; chest width (CW1) - the distance between the lateral faces of the scapulohumeral joints; rump width (RW1) - the distance between the greater trochanters of the femurs; thorax circumference (TC1) - based on the sternum and the withers, passing the tape behind the shoulder; and body compactness index (BCI1) - the ratio between the live weight at slaughter and the body length, in $\mathrm{kg}$ / $\mathrm{cm}$.

The animals were slaughtered in a commercial meat-packing plant (Frigorífico Multicarnes ${ }^{\circledR}$ ), located in the municipality of Maracanaú-CE. After slaughter, the carcasses were identified individually and weighed to obtain the hot carcass weight (HCW), and were then wrapped in plastic bags and kept in a cold room at $4^{\circ} \mathrm{C}$ for $24 \mathrm{~h}$. After chilling, the carcasses were evaluated in the Laboratory of Meats of the Department of Food Engineering at the Federal University of Ceará, where they were weighed to determine the cold carcass weight 
$(\mathrm{CCW})$. The percentage of chilling loss (CL) was determined from the following formula: $\mathrm{CL}$ $=[(\mathrm{HCW}-\mathrm{CCW}) / \mathrm{HCW}] \times 100$. The hot $(\mathrm{HCY})$ and cold carcass $(\mathrm{CCY})$ yields were determined as follows: $\mathrm{HCY}=(\mathrm{HCW} / \mathrm{SW}) \times 100$ and $\mathrm{CCY}=$ $(\mathrm{CCW} / \mathrm{SW}) \times 100$.

The carcasses were hung next to each other, and their conformation was assessed, with an emphasis on the anatomical regions (leg, rump, loin, shoulder, and their muscle planes), and the fat cover was evaluated with an emphasis on the thickness and distribution of the fat planes, based on a fractional scale of 1 to 5 .

The following measurements were taken on the carcasses: external carcass length (ECL) - the distance between the cervicothoracic junction and the first intercoccygeal joint; rump width (RW2) - the maximum width between the trochanters of the femur; rump circumference (RC) - based on the trochanters of the femurs; thorax width (TW) - the maximum width of the thorax; chest width (CW2) - the distance between the lateral faces of the scapulohumeral joints; chest circumference (CC); internal carcass length (ICL) - the distance between the front edge of the pubic bone and the front edge of the first rib at its midpoint; leg length (LL) - the distance between the greater trochanter of the femur and the edge of the tarsometatarsal joint; thorax depth (TD2) - the distance between the sternum and the withers. The carcass (CCI2) and leg (LCI1) compactness indices were also measured, using the following formula: CCI2 $(\mathrm{kg} / \mathrm{cm})=(\mathrm{CCW} / \mathrm{ICL})$, and LCI1 $($ in $\mathrm{cm})=($ RW2/LL $)$.

To obtain the cuts, the carcass was divided, after removing the neck, into two symmetrical parts by making a longitudinal section through the spine. The half-carcass was divided into five anatomical regions according to named commercial cuts: leg, loin, shoulder, rack, and foreshank-breast-flank.
All cuts obtained from the carcass were weighed (CW) on an electronic balance to $10 \mathrm{~g}$ precision, and then the respective yields (CY) were calculated. For these calculations, the reconstituted carcass weight (RCW) - the sum of the weights of all cuts - was calculated to consider the tissue losses that occurred during the process of sectioning the cuts, according to the following formula: $\mathrm{CY}=(\mathrm{CW} / \mathrm{RCW}) \times 100$. The leg compactness index (LCI2, in $\mathrm{kg} / \mathrm{cm}$ ) was also calculated, as the ratio between leg weight and leg length.

Using a graduated ruler, the maximum width (A) and maximum depth (B) of the longissimus lumborum muscle were obtained, between the 12th and 13th left ribs, to determine the loin-eye area (LEA), using the following formula: $\mathrm{LEA}=(\mathrm{A} / 2$ $\times \mathrm{B} / 2) \times \pi$. To lessen the effects of SW and CCW, the LEA was adjusted to these weights, by using the following formulae: LEA $/ 25 \mathrm{~kg} \mathrm{SW}=(\mathrm{LEA} / \mathrm{SW}) \times$ 25 , and LEA $/ 10 \mathrm{~kg} \mathrm{CCW}=(\mathrm{LEA} / \mathrm{CCW}) \times 10$. The subcutaneous fat thickness (SFT) was measured using a digital caliper, for which these adjustments were also made: $\mathrm{SFT} / 25 \mathrm{~kg} \mathrm{SW}=(\mathrm{SFT} / \mathrm{SW}) \times 25$, and $\mathrm{SFT} / 10 \mathrm{~kg} \mathrm{CCW}=(\mathrm{SFT} / \mathrm{CCW}) \times 10$.

The experimental design was completely randomized, with a $2 \times 3$ factorial arrangement with six replicates, consisting of two species and three origins. The collected data were analyzed using the SAS (1999) software for the application of GLM procedures (analysis of variance) and test of means (Tukey, at 5\%).

\section{Results and Discussion}

The goats and sheep of mixed breed, sold for slaughter in Ceará State regardless of the region of origin, showed similar $(P>0.05)$ live weights at slaughter (SW), which varied from about 24 to 25 $\mathrm{kg}$, a mean age of 12 months, and a body condition score close to 2 (Table 1). 
Table 1. Mean values, standard deviation and coefficient of variation (CV) for slaughter weight, body score and body measurements in goats and sheep of different origins sold for slaughter in Ceará.

\begin{tabular}{|c|c|c|c|c|c|c|}
\hline Variable & Species & Quixadá & Sobral & Tauá & Mean & $\mathrm{CV}$ \\
\hline \multirow[t]{2}{*}{ SW (kg) } & Goat & $20.57 \pm 2.91 b$ & $21.50 \pm 0.93 b$ & $27.37 \pm 2.98 \mathrm{a}$ & $23.83 \pm 3.76$ & $15.77 \%$ \\
\hline & Sheep & $23.68 \pm 5.88$ & $24.87 \pm 3.93$ & $27.12 \pm 6.02$ & $25.22 \pm 5.25$ & $20.79 \%$ \\
\hline \multirow[t]{2}{*}{ BS } & Goat & $2.08 \pm 0.66$ & $1.60 \pm 0.22$ & $1.66 \pm 0.26$ & $1.79 \pm 0.47$ & $26.18 \%$ \\
\hline & Sheep & $1.83 \pm 0.41$ & $1.92 \pm 0.38$ & $2.08 \pm 0.38$ & $1.94 \pm 0.38$ & $19.50 \%$ \\
\hline \multirow[t]{2}{*}{$\mathrm{BL}(\mathrm{cm})$} & Goat & $54.5 \pm 2.83 b$ & $59.5 \pm 2.39 \mathrm{a}$ & $65.83 \pm 3.17 \mathrm{Aa}$ & $59.97 \pm 5.59 \mathrm{~A}$ & $9.32 \%$ \\
\hline & Sheep & $54.03 \pm 6.30$ & $56.67 \pm 4.14$ & $56.20 \pm 4.76 \mathrm{~B}$ & $55.63 \pm 4.97 \mathrm{~B}$ & $8.94 \%$ \\
\hline \multirow[t]{2}{*}{$\mathrm{FH}(\mathrm{cm})$} & Goat & $53.58 \pm 3.00 \mathrm{~b}$ & $57.80 \pm 2.51 \mathrm{ab}$ & $60.75 \pm 4.01 \mathrm{a}$ & $57.35 \pm 4.38 \mathrm{~B}$ & $7.63 \%$ \\
\hline & Sheep & $61.13 \pm 3.50$ & $64.83 \pm 6.11$ & $62.78 \pm 5.37$ & $62.92 \pm 5.05 \mathrm{~A}$ & $8.03 \%$ \\
\hline \multirow[t]{2}{*}{$\mathrm{HH}(\mathrm{cm})$} & Goat & $53.58 \pm 3.28 \mathrm{~B}$ & $56.60 \pm 1.29 \mathrm{~B}$ & $61.50 \pm 4.22$ & $57.26 \pm 4.61$ & $8.06 \%$ \\
\hline & Sheep & $61.25 \pm 4.58 \mathrm{~A}$ & $66.22 \pm 5.33 \mathrm{~A}$ & $62.68 \pm 3.68$ & $63.38 \pm 4.81$ & $7.59 \%$ \\
\hline \multirow[t]{2}{*}{ CW1 (cm) } & Goat & $15.66 \pm 1.66$ & $15.00 \pm 0.79$ & $15.16 \pm 2.11$ & $15.29 \pm 1.58$ & $10.34 \%$ \\
\hline & Sheep & $15.50 \pm 2.57$ & $15.37 \pm 0.93$ & $17.00 \pm 3.10$ & $15.96 \pm 2.36$ & $14.82 \%$ \\
\hline \multirow[t]{2}{*}{ RW1 (cm) } & Goat & $11.83 \pm 1.40$ & $11.11 \pm 0.55$ & $11.83 \pm 0.88$ & $11.62 \pm 1.02 \mathrm{~B}$ & $8.81 \%$ \\
\hline & Sheep & $14.57 \pm 3.11$ & $14.18 \pm 2.90$ & $14.87 \pm 3.23$ & $14.54 \pm 2.91 \mathrm{~A}$ & $19.98 \%$ \\
\hline \multirow[t]{2}{*}{$\mathrm{TC} 1(\mathrm{~cm})$} & Goat & $62.00 \pm 1.14 \mathrm{Bb}$ & $65.60 \pm 1.52 \mathrm{ab}$ & $70.33 \pm 4.32 \mathrm{a}$ & $66.00 \pm 4.46 \mathrm{~B}$ & $6.76 \%$ \\
\hline & Sheep & $69.17 \pm 5.64 \mathrm{~A}$ & $69.17 \pm 4.75$ & $70.58 \pm 4.41$ & $69.64 \pm 4.71 \mathrm{~A}$ & $6.76 \%$ \\
\hline \multirow[t]{2}{*}{ BCI1 } & Goat & $0.38 \pm 0.07$ & $0.36 \pm 0.02$ & $0.42 \pm 0.03$ & $0.40 \pm 0.05 \mathrm{~B}$ & $12.23 \%$ \\
\hline & Sheep & $0.43 \pm 0.07$ & $0.44 \pm 0.04$ & $0.48 \pm 0.08$ & $0.45 \pm 0.07 \mathrm{~A}$ & $14.55 \%$ \\
\hline
\end{tabular}

Means followed by different small letters in rows and by different capital letters in columns differ by the Tukey test at $5 \%$ probability. $\mathrm{SW}=$ slaughter weight; $\mathrm{BS}$ = body score; $\mathrm{BL}=$ body length; $\mathrm{FH}=$ forequarter height; $\mathrm{HH}=$ hindquarter height; $\mathrm{CW} 1$ = chest width; RW1 = rump width; TC1 = thorax circumference; BCI1 = body compactness index.

Thus, it can be inferred that mixed-breed goats and sheep sold in the street markets of the capital for slaughter, and reared in extensive conditions, which form the largest part of the state's herd, reach their slaughter weight at an advanced age and with a lean body condition score, demonstrating low precocity and little ability for meat production. These results should cause us to question the current form of rearing these herds in the state of Ceará.

The consumer markers establish optimal weights, to avoid slaughter under unsatisfactory conditions of muscle development and fat cover, since a carcass is valued based on the ratio between body weight and age, given that consumers seek heavier weights at younger ages (SILVA SOBRINHO; MORENO, 2009). The sheep and goats from the Brazilian Northeast have in general, a smaller size and lower weight than animals of breeds that are specialized for meat production. Therefore, the optimal slaughter weight of these animals should be defined for each breed group, considering the preferences of the consumer market (ZAPATA et al., 2001). According to Siqueira et al. (2001), the feed conversion of the lamb decreases as its age and live weight increase; thus, as the slaughter age is anticipated, feed conversion is improved.

The goats originating from the region of Tauá showed a higher SW than those from the other regions, probably as a result of the genetic breeding and productive improvement programs for this species carried out in that region in the last few years through partnerships among the Instituto Centro de Ensino Tecnológico (CENTEC), Banco do Nordeste (BNB), Empresa de Assistência Técnica e Extensão Rural do Ceará (EMATERCE), Serviço Brasileiro de Apoio às Micro e Pequenas Empresas 
(SEBRAE), and Prefeitura de Tauá (ALCÂNTARA NETO, 2005).

The observed measurements (Table 1) demonstrate variations in the size and length of the goats reared in this study, probably due to the variety of breeds, breed groups, and their crossbreeds, which have been introduced into farms at random time-points and with no control. This has sometimes occurred under governmental programs for the selection and breeding of these animals, forming herds with differences in conformation and with regional variations. In contrast, from the statistical similarity of the means of the three studied origins, we can observe the homogeneity of the sheep regarding the slaughter weights and measurements of the animals raised and sold in the state. According to Zapata et al. (2001), the breed groups of sheep and goats of the Brazilian Northeast are varied, with crossbreeds predominating, which hinders an appropriate classification based on pure breeds or lines.

Comparing the body measurements between the species, the goats showed a higher $(P<0.05)$ body length (BL) and lower $(P<0.05)$ forequarter height (FH), rump width (RW1) and thorax circumference (TC1) than the sheep, and no significant differences were found between the species $(P>0.05)$ for hindquarter height $(\mathrm{HH})$ and chest width. Sousa et al. (2009) compared feedlot-finished crossbred goats with sheep, and observed superiority in the height at the withers and $\mathrm{TC} 1$ in the sheep compared with the goats; concerning the measurements of height at the withers, BL, and leg length (LL), the species were similar statistically. Thus, even under the same rearing conditions, with similar weights and ages, caprine and ovine species can have different body measurements. These measurements are important, as they have been used as a method to predetermine carcass characteristics (YÁÑES et al., 2004; PINHEIRO; JORGE, 2010).

The body compactness index (BCI1) has been used as a good indicator of the body tissue composition; as this value increases, carcasses with a greater meat content are expected, and thus, a greater proportion of edible material (YÁÑEZ et al., 2004). In this study, there were no differences between the studied animal origins; however, the sheep showed a higher BCI1 than the goats (Table 1). Sousa et al. (2009) observed that Santa Inês lambs and Boer crossbred goats reached higher BCI1 values than Anglo-Nubian crossbred goats.

The goats sold for slaughter in Ceará state from the different evaluated origins, had similar hot $(\mathrm{HCW})$ and cold $(\mathrm{CCW})$ carcass weights, with mean values close to $9 \mathrm{~kg}$ (Table 2). Although the goats from Tauá displayed a higher SW than animals from the other regions (Table 1), a similarity $(P>0.05)$ in the $\mathrm{HCW}$ and $\mathrm{CCW}$ was observed between the origins based on the low carcass yields shown by the animals from Tauá, even though no differences were found for these yields between the origins (Table 2). The evaluated sheep had a similar HCW and CCW $(P>0.05)$, averaging approximately $10 \mathrm{~kg}$. No difference was detected $(P>0.05)$ for $\mathrm{HCW}$ and $\mathrm{CCW}$ between the studied species (Table 2).

The mean values of carcass yields of goats and sheep varied from about 38.4 to $39.2 \%$ for $\mathrm{CCY}$ and between 39.0 and $40.3 \%$ for HCY, with no difference $(P>0.05)$ between the origins or species (Table 2). Oliveira et al. (2008) obtained a HCY of $43.34 \%$ in mixed-breed goats reared in a semiintensive system in Ceará State, which is lower than the value observed for Anglo-Nubian (45.60\%) and Boer $(45.86 \%)$ crossbred goats. 
Table 2. Means, standard deviation and coefficient of variation (CV) for weights and yields of hot and cold carcass and chilling loss in goats and sheep sold for slaughter from different origins of Ceará.

\begin{tabular}{|c|c|c|c|c|c|c|}
\hline Variable & Species & Quixadá & Sobral & Tauá & Mean & $\mathrm{CV}$ \\
\hline \multirow[t]{2}{*}{$\mathrm{HCW}(\mathrm{kg})$} & Goat & $9.05 \pm 2.89$ & $8.97 \pm 1.54$ & $9.64 \pm 2.11$ & $9.25 \pm 2.16$ & $23.31 \%$ \\
\hline & Sheep & $9.57 \pm 3.17$ & $10.06 \pm 1.50$ & $10.75 \pm 1.92$ & $10.17 \pm 2.23$ & $21.96 \%$ \\
\hline \multirow[t]{2}{*}{ CCW (kg) } & Goat & $8.96 \pm 2.89$ & $8.72 \pm 1.30$ & $9.47 \pm 1.95$ & $9.04 \pm 2.09$ & $23.10 \%$ \\
\hline & Sheep & $9.55 \pm 3.25$ & $9.89 \pm 1.46$ & $10.39 \pm 2.15$ & $9.89 \pm 2.27$ & $22.96 \%$ \\
\hline \multirow[t]{2}{*}{ HCY (\%) } & Goat & $40.96 \pm 9.11$ & $41.75 \pm 7.10$ & $35.09 \pm 4.06$ & $38.98 \pm 7.62$ & $18.63 \%$ \\
\hline & Sheep & $40.29 \pm 3.35$ & $40.86 \pm 1.42$ & $39.15 \pm 1.01$ & $40.33 \pm 2.43$ & $6.04 \%$ \\
\hline \multirow[t]{2}{*}{ CCY (\%) } & Goat & $40.01 \pm 9.11$ & $40.44 \pm 6.00$ & $35.06 \pm 9.31$ & $38.39 \pm 8.28$ & $21.55 \%$ \\
\hline & Sheep & $39.62 \pm 3.36$ & $39.57 \pm 1.72$ & $38.29 \pm 1.51$ & $39.16 \pm 2.40$ & $6.13 \%$ \\
\hline \multirow[t]{2}{*}{ CL (\%) } & Goat & $1.39 \pm 0.75$ & $2.45 \pm 1.04$ & $2.98 \pm 1.79$ & $2.26 \pm 1.39$ & $61.67 \%$ \\
\hline & Sheep & $2.30 \pm 0.83$ & $1.84 \pm 0.49$ & $3.18 \pm 1.23$ & $2.86 \pm 2.67$ & $93.42 \%$ \\
\hline
\end{tabular}

Means followed by different small letters in rows and by different capital letters in columns differ by the Tukey test at $5 \%$ probability. $\mathrm{HCW}=$ hot carcass weight; $\mathrm{CCW}=$ cold carcass weight; $\mathrm{HCY}=$ hot carcass yield; $\mathrm{CCY}=$ cold carcass yield; $\mathrm{CL}=$ chilling loss.

The carcass yield values found in this study are considered low, and imply that $60 \%$ of the body weight of mixed-breed goats and sheep that are reared in extensive systems in Ceará State consists of non-carcass components, which might represent economic losses, because although the region has the habit of consuming the visceral organs of small ruminants, the prices paid for these products are lower than those paid for the meat. It should also be stressed that because of the adopted rearing system - in which animals are exposed to barbed wire and diseases such as caseous lymphadenitis and ectoparasites, in addition to the lack of care during skinning in clandestine slaughterhouses - the skin of these animals can be damaged, which depreciates this important product.

The chilling losses (CL) represent the loss of moisture from the muscle surfaces during the chilling of the carcass; this variable can be influenced by several factors related to the refrigerating conditions of the room and carcass qualitative traits, such as the amount of fat cover (MARTINS et al., 2000). In this study, no difference was found in the CL of the carcasses of either studied species (Table 2), and despite the reduced amount of subcutaneous fat observed in the carcasses, the obtained values are within the mean range cited in the literature for goats 1.90 to $2.17 \%$, (OLIVEIRA et al., 2008); 2.0 to $5.3 \%$, (SOUSA et al., 2009) and sheep 3.0 to $3.5 \%$, (LANDIM et al., 2007); 2.04 to $3.06 \%$, (CARTAXO et al., 2011).

The conformation measures the amount of muscle in the carcass, which can be obtained subjectively by a visual assessment; objectively, from carcass morphometrics; or from indices and the loin-eye area (CEZAR; SOUSA, 2007). The goats sold for slaughter in the state showed heterogeneity in relation to the carcass conformation, which was classified as poor, with values ranging from 1.00 to 1.42 , and an overall mean for the species of 1.24 , which is statistically higher $(P<0.05)$ than the mean value for sheep. This mean value, in turn, showed greater uniformity in the carcass conformation, with values unanimously equal to 1.00 , which are also classified as poor (Table 3). It is noteworthy that these animals were approximately one year old. These results demonstrate the low quality of the carcasses of the animals of both species, reared under such conditions and sold in Ceará State, especially during the dry season of the year. 
Table 3. Means, standard deviation and coefficient of variation (CV) for quantitative and qualitative carcass traits in goats and sheep sold for slaughter from different origins of Ceará.

\begin{tabular}{|c|c|c|c|c|c|c|}
\hline Variable & Species & Quixadá & Sobral & Tauá & Mean & $\mathrm{CV}$ \\
\hline \multirow[t]{2}{*}{ CONF } & Goat & $1.42 \pm 0.20 \mathrm{~A}$ & $1.10 \pm 0.22$ & $1.17 \pm 0.26$ & $1.24 \pm 0.26 \mathrm{~A}$ & $20.82 \%$ \\
\hline & Sheep & $1.00 \pm 0.00 \mathrm{~B}$ & $1.00 \pm 0.00$ & $1.00 \pm 0.00$ & $1.00 \pm 0.00 \mathrm{~B}$ & $0.00 \%$ \\
\hline \multirow[t]{2}{*}{$\mathrm{FC}$} & Goat & $1.42 \pm 0.20 \mathrm{~A}$ & $1.40 \pm 0.22 \mathrm{~A}$ & $1.17 \pm 0.26$ & $1.32 \pm 0.25 \mathrm{~A}$ & $18.61 \%$ \\
\hline & Sheep & $1.00 \pm 0.00 \mathrm{~B}$ & $1.00 \pm 0.00 \mathrm{~B}$ & $1.00 \pm 0.00$ & $1.00 \pm 0.00 \mathrm{~B}$ & $0.00 \%$ \\
\hline \multirow[t]{2}{*}{$\mathrm{ECL}(\mathrm{cm})$} & Goat & $48.58 \pm 3.00$ & $51.20 \pm 2.58$ & $53.33 \pm 3.33 \mathrm{~A}$ & $51.03 \pm 3.49 \mathrm{~A}$ & $6.85 \%$ \\
\hline & Sheep & $44.00 \pm 4.65$ & $46.92 \pm 4.41$ & $44.67 \pm 5.57 \mathrm{~B}$ & $45.19 \pm 4.78 \mathrm{~B}$ & $10.58 \%$ \\
\hline \multirow[t]{2}{*}{ RW2 (cm) } & Goat & $17.15 \pm 2.06$ & $16.40 \pm 1.24$ & $17.58 \pm 1.77$ & $17.09 \pm 1.72$ & $10.04 \%$ \\
\hline & Sheep & $17.50 \pm 1.90$ & $17.08 \pm 1.72$ & $18.00 \pm 4.45$ & $17.53 \pm 1.46$ & $8.33 \%$ \\
\hline \multirow[t]{2}{*}{$\mathrm{RC}(\mathrm{cm})$} & Goat & $47.17 \pm 4.82$ & $47.70 \pm 2.54$ & $48.50 \pm 2.94$ & $47.79 \pm 3.46 \mathrm{~B}$ & $7.23 \%$ \\
\hline & Sheep & $49.75 \pm 5.97$ & $51.00 \pm 2.12$ & $52.75 \pm 5.29$ & $51.17 \pm 4.65 \mathrm{~A}$ & $9.09 \%$ \\
\hline \multirow[t]{2}{*}{$\mathrm{TW}(\mathrm{cm})$} & Goat & $15.83 \pm 1.47$ & $16.20 \pm 0.84$ & $16.42 \pm 1.63$ & $16.15 \pm 1.32 \mathrm{~B}$ & $8.18 \%$ \\
\hline & Sheep & $18.75 \pm 1.67$ & $18.08 \pm 1.40$ & $19.50 \pm 2.83$ & $18.78 \pm 2.02 \mathrm{~A}$ & $10.78 \%$ \\
\hline \multirow[t]{2}{*}{$\mathrm{CW} 2(\mathrm{~cm})$} & Goat & $13.75 \pm 1.51$ & $13.50 \pm 0.71$ & $13.50 \pm 1.37$ & $13.59 \pm 1.20$ & $8.85 \%$ \\
\hline & Sheep & $13.42 \pm 11.56$ & $13.75 \pm 0.76$ & $13.67 \pm 0.82$ & $13.61 \pm 1.05$ & $7.72 \%$ \\
\hline \multirow[t]{2}{*}{$\mathrm{CC}(\mathrm{cm})$} & Goat & $28.42 \pm 3.12$ & $27.80 \pm 1.92 \mathrm{~B}$ & $27.50 \pm 1.73$ & $27.91 \pm 2.25 \mathrm{~B}$ & $8.07 \%$ \\
\hline & Sheep & $31.08 \pm 4.57$ & $33.83 \pm 3.66 \mathrm{~A}$ & $31.08 \pm 2.73$ & $32.00 \pm 3.75 \mathrm{~A}$ & $11.70 \%$ \\
\hline \multirow[t]{2}{*}{$\operatorname{ICL}(\mathrm{cm})$} & Goat & $45.67 \pm 2.90$ & $46.90 \pm 3.81$ & $50.17 \pm 3.37$ & $47.62 \pm 3.72$ & $7.81 \%$ \\
\hline & Sheep & $46.00 \pm 4.60$ & $49.00 \pm 5.55$ & $47.50 \pm 2.07$ & $47.50 \pm 4.26$ & $8.97 \%$ \\
\hline \multirow[t]{2}{*}{$\mathrm{CCI} 2$} & Goat & $0.20 \pm 0.05$ & $0.19 \pm 0.02$ & $0.19 \pm 0.03$ & $0.19 \pm 0.04$ & $18.52 \%$ \\
\hline & Sheep & $0.20 \pm 0.05$ & $0.20 \pm 0.02$ & $0.22 \pm 0.04$ & $0.21 \pm 0.03$ & $16.75 \%$ \\
\hline \multirow[t]{2}{*}{$\mathrm{LL}(\mathrm{cm})$} & Goat & $45.00 \pm 2.88 b$ & $48.20 \pm 2.68 \mathrm{ab}$ & $51.00 \pm 3.36 \mathrm{a}$ & $48.06 \pm 3.83$ & $7.97 \%$ \\
\hline & Sheep & $45.33 \pm 3.91$ & $49.83 \pm 4.13$ & $50.33 \pm 2.25$ & $48.50 \pm 4.04$ & $8.34 \%$ \\
\hline \multirow[t]{2}{*}{ TD2 (cm) } & Goat & $17.33 \pm 1.53$ & $18.10 \pm 0.89$ & $19.41 \pm 1.77$ & $18.29 \pm 1.66$ & $9.07 \%$ \\
\hline & Sheep & $17.75 \pm 1.25$ & $20.00 \pm 2.61$ & $18.58 \pm 1.74$ & $18.78 \pm 2.07$ & $11.01 \%$ \\
\hline
\end{tabular}

Means followed by different small letters in rows and by different capital letters in columns differ by the Tukey test at $5 \%$ probability. $\mathrm{CONF}=$ conformation $; \mathrm{FC}=$ fat cover; $\mathrm{ECL}=$ external carcass length; $\mathrm{RW} 2=$ rump width $; \mathrm{RC}=$ rump circumference; $\mathrm{TW}=$ thorax width; CW2 = chest width; $\mathrm{CC}=$ chest circumference; $\mathrm{ICL}=$ internal carcass length; $\mathrm{CCI} 2=$ carcass compactness index; $\mathrm{LL}=$ leg length; TD2 = thorax depth.

The carcass fat cover is related to the production of fat within it, which can be assessed subjectively by visual assessment, or by measuring the subcutaneous fat thickness (CEZAR; SOUSA, 2007). It was observed that goats reared in extensive conditions in the state had a degree of fat cover that was classified as too lean, with values varying between 1.00 and 1.42 , with an overall mean of 1.32 . This is statistically higher $(P<0.05)$ than the overall mean for sheep, whose fat cover uniform value was 1.00 , which was also classified as too lean (1.00), i.e., the superficial fat, or fat cover, was sparse in practically all carcasses of the evaluated animals (Table 3 ).
Although the population is more aware of the harm caused by foods with a high saturated-fat content, which is found in animal-derived products, and thus now seek healthier foods, the presence of a minimum amount of fat in the carcass is essential for the maintenance of the sensory quality of goat and sheep meat. According to Madruga (2003), the best carcass is one that contains the maximum proportion of muscle, the minimum proportion of bones, and a reasonable proportion of fat, which is required by the intended market, and which is sufficient to ensure meat juiciness, as well as its good appearance and preservation. 
The observed results might have been influenced by the time of purchase of the animals, at the end of the dry season of the year. Because of the adopted rearing system, animals in this period experience nutritional restrictions that compromise the quality of the produced carcasses. However, the demand for meat of these species considerably increases in this period because of end-of-year festivities. Therefore, local producers should be aware of these market niches, and depending on the modernization of the production system, reduce the seasonalityof production. This will improve the quantity and mainly quality of sheep and goat meat and stimulate regional consumption, so that it is no longer restricted to celebrations and weekends and becomes a dietary habit. This will also reduce the import of these meats from other regions and countries and strengthen the sector in Ceará State. Therefore, technologies should be adapted to the production conditions of these species within the state, especially regarding their nutritional management, including better techniques for the production and preservation of forage for the dry season and a rational use of available food resources. This will increase product quality and provide producers with better financial returns and the consumers with high-quality meat. Before considering the genetic breeding of the species reared in the state, by introducing genetically superior breeds, the nutrition and health of the herd should be prioritized, in terms of the characteristics of each species and the physiological state of the animals with regard to the nutritional requirements and degree of sanitary care.

Regarding the carcass morphometrics (Table 3), except for leg length (LL) between goats from Tauá and Quixadá, the carcass width and length, as well as its compactness index (CCI2) were statistically similar between the evaluated origins. However, comparing the carcass measurements between the species (Table 3), goats showed higher values for external carcass length (ECL) than sheep, which was expected, because the same difference was also observed for the body length (BL) of the live animal (Table 1). However, sheep carcasses showed a higher rump circumference (RC), thorax width (TW) and chest circumference (CC) than those of goats. According to Madruga et al. (1999), because they are small-sized animals, the carcass of goats is small, lean, and not very compact.

The loin-eye area (LEA) has been used to estimate the carcass muscularity, i.e., the amount of marketable meat in contains, and it is correlated with the muscle/bone ratio in the carcass cuts (SUGUISAWA et al., 2006; CEZAR; SOUSA, 2010). In this study, the four measurements of width (A) and length (B) of the longissimus lumborum muscle of the carcasses of the evaluated animals did not differ statistically $(P>0.05)$ between the origins, influencing the LEA both in the direct measurement from the animal loin, and in the LEA adjusted to $25 \mathrm{~kg} \mathrm{SW}$ and $10 \mathrm{~kg} \mathrm{CCW}$, which also did not differ $(P>0.05)$ between the evaluated origins. These adjustments were made to evaluate the possible effect of the differences between the weight of animals and carcasses on the LEA. Hence, among the studied origins, there were no differences between measurements $\mathrm{A}$ and $\mathrm{B}$, or for LEA and LEA adjusted to $25 \mathrm{~kg}$ SW and 10 $\mathrm{kg} \mathrm{CCW}$ in the animals sold for slaughter in Ceará State. However, statistical differences $(P<0.05)$ in the mean LEA and LEA adjusted to $10 \mathrm{~kg} \mathrm{CCW}$ were observed between sheep and goats (Table 4). When the SW of the animals was adjusted to $25 \mathrm{~kg}$, the overall means between the species were similar, indicating that variations in the animals' slaughter weight might mask the LEA values. Sousa et al. (2009) observed that Santa Inês sheep showed a larger carcass LEA than $1 / 2$ Boer $\times 1 / 2$ mixed-breed and $1 / 2$ Anglo-Nubian $\times 1 / 2$ mixed-breed goats reared in the same production system and slaughtered at the same weights and age. 
Table 4. Means, standard deviation and coefficient of variation (CV) for measurements of the longissimus lumborum muscle in goats and sheep sold for slaughter from different origins of Ceará.

\begin{tabular}{lcrrrrc}
\hline Variable & Species & \multicolumn{1}{c}{ Quixadá } & \multicolumn{1}{c}{ Sobral } & Tauá & Mean & CV \\
\hline $\mathrm{A}(\mathrm{cm})$ & Goat & $4.82 \pm 0.62$ & $5.10 \pm 0.42$ & $5.23 \pm 0.75$ & $5.05 \pm 0.61$ & $12.12 \%$ \\
& Sheep & $5.50 \pm 1.08$ & $5.22 \pm 0.93$ & $5.48 \pm 0.30$ & $5.40 \pm 0.80$ & $14.86 \%$ \\
$\mathrm{~B}(\mathrm{~cm})$ & Goat & $2.27 \pm 0.64$ & $1.92 \pm 0.40$ & $1.98 \pm 0.39$ & $2.06 \pm 0.49$ & $23.60 \%$ \\
& Sheep & $2.37 \pm 0.50$ & $2.40 \pm 0.46$ & $2.32 \pm 0.48$ & $2.36 \pm 0.45$ & $19.06 \%$ \\
AOL $(\mathrm{cm} 2)$ & Goat & $8.51 \pm 2.49$ & $7.77 \pm 2.08$ & $8.30 \pm 2.62$ & $8.22 \pm 2.29 \mathrm{~B}$ & $27.90 \%$ \\
& Sheep & $10.44 \pm 4.21$ & $9.99 \pm 3.06$ & $9.90 \pm 1.63$ & $10.11 \pm 2.97 \mathrm{~A}$ & $29.34 \%$ \\
AOL/25kg PVA & Goat & $9.57 \pm 2.17$ & $9.05 \pm 2.46$ & $7.65 \pm 2.67$ & $8.74 \pm 2.44$ & $27.92 \%$ \\
& Sheep & $10.76 \pm 1.41$ & $10.16 \pm 3.20$ & $9.49 \pm 2.51$ & $10.13 \pm 2.39$ & $23.61 \%$ \\
AOL/10kg PCF & Goat & $9.50 \pm 1.56$ & $8.61 \pm 1.45$ & $8.61 \pm 1.95$ & $8.92 \pm 1.63 \mathrm{~B}$ & $18.30 \%$ \\
& Sheep & $10.90 \pm 0.50$ & $10.19 \pm 3.18$ & $9.86 \pm 2.31$ & $10.32 \pm 2.19 \mathrm{~A}$ & $21.27 \%$ \\
STF $(\mathrm{mm})$ & Goat & $0.81 \pm 0.61$ & $0.61 \pm 0.17$ & $0.90 \pm 0.45$ & $0.78 \pm 0.45 \mathrm{~B}$ & $57.38 \%$ \\
& Sheep & $1.23 \pm 0.34$ & $1.36 \pm 0.32$ & $1.08 \pm 0.44$ & $1.22 \pm 0.37 \mathrm{~A}$ & $29.87 \%$ \\
$\mathrm{STF} / 25 \mathrm{~kg}$ SW & Goat & $0.87 \pm 0.50$ & $0.71 \pm 0.19$ & $0.83 \pm 0.42$ & $0.81 \pm 0.39 \mathrm{~B}$ & $47.90 \%$ \\
& Sheep & $1.32 \pm 0.32$ & $1.40 \pm 0.39$ & $1.01 \pm 1.35$ & $1.24 \pm 0.38 \mathrm{~A}$ & $30.28 \%$ \\
$\mathrm{STF} / 10 \mathrm{~kg} \mathrm{CCW}$ & Goat & $0.83 \pm 0.30$ & $0.68 \pm 0.18 \mathrm{~B}$ & $0.91 \pm 0.36$ & $0.81 \pm 0.29 \mathrm{~B}$ & $35.74 \%$ \\
& Sheep & $1.35 \pm 0.32$ & $1.41 \pm 0.39 \mathrm{~A}$ & $1.06 \pm 0.36$ & $1.27 \pm 0.38 \mathrm{~A}$ & $29.76 \%$ \\
\hline
\end{tabular}

Means followed by different small letters in rows and by different capital letters in columns differ by the Tukey test at $5 \%$ probability. $\mathrm{A}=$ maximum width of the muscle; $\mathrm{B}=$ maximum length of the muscle; LEA = loin-eye area; SFT = subcutaneous fat thickness.

The subcutaneous fat thickness (SFT) has been used in studies of carcass quality, because of its positive correlation with the total amount of fat accumulated in the animal body (SILVA SOBRINHO, 2001a). In this study, neither the SFT measured in the animal, nor the SFT adjusted to $25 \mathrm{~kg} \mathrm{SW}$ and $10 \mathrm{~kg} \mathrm{CCW}$, showed statistical differences between the origins of the evaluated species. However, the mean SFT and adjusted SFT values of the sheep carcasses were statistically superior to those of goats (Table 4). Sousa et al. (2009) also observed that sheep carcasses showed a greater thickness of fat cover than goats. Cezar and Sousa (2006) reported that one of the most remarkable differences between small ruminant species is that the subcutaneous adipose tissue in the caprine species is less developed or sparse, and is almost entirely deposited within the body cavities.

Despite being superior to that of goats, the maximum SFT observed in the sheep carcasses did not reach $1.5 \mathrm{~mm}$ (Table 4). According to Sañudo et al. (2000), meat from sheep carcasses with 2.0 $\mathrm{mm}$ or less subcutaneous fat are classified as having less flavor and providing less satisfaction in sensory tests.

It can be inferred that extensively reared sheep sold for slaughter in Ceará State, show higher mean LEA and SFT values than goats, demonstrating that ovine species have a greater potential for meat production in similar rearing conditions.

The reconstituted carcass weight (RCW) is the sum of the weight of all cuts individually; thus, the percentage of the cut will be related to RCW, and not to $\mathrm{CCW}$, which makes the cut/carcass ratio more precise, given the losses that occur during the separation of the carcass cuts. In this study, the $\mathrm{RCW}$ of goats and sheep showed the same response as $\mathrm{CCW}$, with no differences related to the origin or species (Table 5). 
Table 5. Means, standard deviation and coefficient of variation (CV) for reconstituted carcass weight (RCW), leg compactness indices (LCIs) and weight and yield of commercial cuts in goats and sheep sold for slaughter from different origins of Ceará.

\begin{tabular}{|c|c|c|c|c|c|c|}
\hline Variable & Species & Quixadá & Sobral & Tauá & Mean & $\mathrm{CV}$ \\
\hline \multirow[t]{2}{*}{ RCW (kg) } & Goat & $8.95 \pm 2.95$ & $8.69 \pm 1.34$ & $9.37 \pm 2.02$ & $9.02 \pm 2.13$ & $23.58 \%$ \\
\hline & Sheep & $9.44 \pm 3.15$ & $9.92 \pm 1.46$ & $10.29 \pm 2.09$ & $9.88 \pm 2.30$ & $22.57 \%$ \\
\hline \multirow[t]{2}{*}{ LCI1 (kg/cm) } & Goat & $0.033 \pm 0.010$ & $0.032 \pm 0.005$ & $0.030 \pm 0.000$ & $0.032 \pm 0.006$ & $20.02 \%$ \\
\hline & Sheep & $0.036 \pm 0.007$ & $0.035 \pm 0.003$ & $0.036 \pm 0.006$ & $0.036 \pm 0.005$ & $14.90 \%$ \\
\hline \multirow[t]{2}{*}{ LCI2 (cm) } & Goat & $0.38 \pm 0.04$ & $0.34 \pm 0.01$ & $0.35 \pm 0.02$ & $0.36 \pm 0.03$ & $9.03 \%$ \\
\hline & Sheep & $0.39 \pm 0.02$ & $0.35 \pm 0.04$ & $0.36 \pm 0.02$ & $0.36 \pm 0.03$ & $8.80 \%$ \\
\hline \multirow[t]{2}{*}{ Leg (kg) } & Goat & $1.52 \pm 0.45$ & $1.48 \pm 0.28$ & $1.54 \pm 0.25$ & $1.49 \pm 0.32 \mathrm{~B}$ & $21.22 \%$ \\
\hline & Sheep & $1.68 \pm 0.52$ & $1.80 \pm 0.23$ & $1.86 \pm 0.35$ & $1.74 \pm 0.36 \mathrm{~A}$ & $20.48 \%$ \\
\hline \multirow[t]{2}{*}{ Shoulder (kg) } & Goat & $0.99 \pm 0.31$ & $0.99 \pm 0.15$ & $1.05 \pm 0.20$ & $1.01 \pm 0.22$ & $21.53 \%$ \\
\hline & Sheep & $0.91 \pm 0.31$ & $1.00 \pm 0.12$ & $1.04 \pm 0.20$ & $0.99 \pm 0.22$ & $22.51 \%$ \\
\hline \multirow[t]{2}{*}{ Loin (kg) } & Goat & $0.39 \pm 0.19$ & $0.35 \pm 0.04$ & $0.37 \pm 0.07$ & $0.37 \pm 0.11$ & $28.86 \%$ \\
\hline & Sheep & $0.40 \pm 0.17$ & $0.42 \pm 0.06$ & $0.39 \pm 0.09$ & $0.39 \pm 0.09$ & $23.56 \%$ \\
\hline \multirow[t]{2}{*}{ Neck (kg) } & Goat & $0.77 \pm 0.23$ & $0.80 \pm 0.15$ & $0.96 \pm 0.43$ & $0.85 \pm 0.30$ & $35.00 \%$ \\
\hline & Sheep & $0.82 \pm 0.30$ & $0.89 \pm 0.20$ & $0.98 \pm 0.20$ & $0.89 \pm 0.23$ & $26.00 \%$ \\
\hline \multirow[t]{2}{*}{ Rack (kg) } & Goat & $0.66 \pm 0.21$ & $0.71 \pm 0.11$ & $0.75 \pm 0.16$ & $0.69 \pm 0.18 \mathrm{~B}$ & $26.05 \%$ \\
\hline & Sheep & $0.82 \pm 0.37$ & $0.77 \pm 0.13$ & $0.79 \pm 0.22$ & $0.84 \pm 0.24 \mathrm{~A}$ & $28.46 \%$ \\
\hline \multirow{2}{*}{$\begin{array}{l}\text { Foreshank-breast-flan } \\
(\mathrm{kg})\end{array}$} & Goat & $0.59 \pm 0.31$ & $0.60 \pm 0.08$ & $0.57 \pm 0.09$ & $0.58 \pm 0.15$ & $28.18 \%$ \\
\hline & Sheep & $0.59 \pm 0.15$ & $0.54 \pm 0.12$ & $0.59 \pm 0.19$ & $0.57 \pm 0.12$ & $22.29 \%$ \\
\hline \multirow[t]{2}{*}{$\operatorname{Leg}(\%)$} & Goat & $33.37 \pm 1.19$ & $32.94 \pm 0.90 \mathrm{~B}$ & $33.03 \pm 2.41$ & $33.12 \pm 1.58 \mathrm{~B}$ & $4.77 \%$ \\
\hline & Sheep & $35.03 \pm 0.89$ & $35.60 \pm 1.05 \mathrm{~A}$ & $35.37 \pm 1.07$ & $35.33 \pm 0.97 \mathrm{~A}$ & $2.76 \%$ \\
\hline \multirow[t]{2}{*}{ Shoulder (\%) } & Goat & $22.23 \pm 0.46 \mathrm{~A}$ & $22.62 \pm 0.71 \mathrm{~A}$ & $22.58 \pm 0.92 \mathrm{~A}$ & $22.47 \pm 0.70 \mathrm{~A}$ & $3.12 \%$ \\
\hline & Sheep & $19.37 \pm 0.49 \mathrm{~B}$ & $20.21 \pm 0.33 \mathrm{~B}$ & $20.34 \pm 0.80 \mathrm{~B}$ & $19.97 \pm 0.70 \mathrm{~B}$ & $3.49 \%$ \\
\hline \multirow[t]{2}{*}{ Loin (\%) } & Goat & $8.40 \pm 0.71$ & $8.02 \pm 0.56$ & $7.82 \pm 0.40$ & $8.08 \pm 0.59$ & $7.30 \%$ \\
\hline & Sheep & $7.95 \pm 0.38$ & $8.33 \pm 0.35$ & $7.45 \pm 0.74$ & $7.91 \pm 0.62$ & $7.80 \%$ \\
\hline \multirow[t]{2}{*}{ Neck (\%) } & Goat & $8.71 \pm 0.37$ & $9.20 \pm 0.36$ & $9.87 \pm 2.24$ & $9.26 \pm 1.38$ & $14.91 \%$ \\
\hline & Sheep & $8.62 \pm 0.32$ & $8.94 \pm 0.97$ & $9.43 \pm 0.38$ & $9.00 \pm 0.68$ & $7.58 \%$ \\
\hline Rack (\%) & Goat & $14.88 \pm 0.60 \mathrm{~B}$ & $15.08 \pm 0.14$ & $15.66 \pm 1.37$ & $15.21 \pm 0.91 \mathrm{~B}$ & $5.97 \%$ \\
\hline \multirow{3}{*}{$\begin{array}{l}\text { Foreshank-breast-flan } \\
(\%)\end{array}$} & Sheep & $17.42 \pm 1.33 \mathrm{~A}$ & $16.83 \pm 1.04$ & $16.57 \pm 1.14$ & $16.94 \pm 1.17 \mathrm{~A}$ & $6.88 \%$ \\
\hline & Goat & $12.42 \pm 1.45$ & $12.14 \pm 0.92 \mathrm{~A}$ & $11.05 \pm 1.04$ & $11.85 \pm 1.27 \mathrm{~A}$ & $10.68 \%$ \\
\hline & Sheep & $11.60 \pm 0.80$ & $10.13 \pm 0.46 \mathrm{~B}$ & $10.80 \pm 0.89$ & $10.84 \pm 0.93 \mathrm{~B}$ & $8.58 \%$ \\
\hline
\end{tabular}

Means followed by different small letters in rows and by different capital letters in columns differ by the Tukey test at $5 \%$ probability. LCI1 = carcass rump width/leg length; LCI2 = leg weight/leg length.

The carcass and leg compactness indices evaluate the amount of muscle and fat in relation to length. In this study, two leg compactness indices (LCI) were obtained: the first was determined as the ratio between the carcass rump width and its leg length, LCI1 $(\mathrm{cm})$, and the second, LCI2 $(\mathrm{kg} / \mathrm{cm})$, was calculated as the ratio between the leg weight and its length. In the evaluated animals, no difference was detected $(P>0.05)$ in the LCI between origins or species (Table 5).
No difference was found $(P>0.05)$ in the weight of cuts between the origins. However, the overall means of the weights of leg and rack were higher in sheep than in goats (Table 5). Souza et al. (2009) obtained a greater weight of leg and foreshankbreast-flank in Santa Inês sheep compared with $1 / 2$ Aglo-Nubian $\times 1 / 2$ mixed-breed goats, although $1 / 2$ Boer $\times 1 / 2$ mixed-breed goats showed similar values to those of other breed groups. 
The overall means for the percentages of leg and rack were higher $(P<0.05)$ in sheep than in goats. However, the goats had a superior percentage of foreshank-breast-flank and shoulder $(P<0.05)$, and the goats from all studied regions showed a higher percentage of shoulder than the sheep (Table 5). Sousa et al. (2009) observed no differences in the proportions of the commercial cuts between sheep and goats reared in a semiintensive system.

Although the slaughter weight, age, body condition score, and some body and morphometric measurements were similar between different origins and the species, the goats and sheep had different body structure characteristics, deposition of fat, and distribution of muscle mass within the carcasses and commercial cuts. Sheep had a higher FH, RW1, TC1, BCI1, RC, CC, TW, LEA, SFT, and weight and proportion of leg, which is a prime cut, in addition to a heavier weight and percentage of rack than goats, whereas the latter had a higher BL, conformation, fat cover, ECL, and percentages of shoulder and foreshank-breast-flank than sheep.

\section{Conclusions}

Mixed-breed goats and sheep reared in extensive systems in Ceará State and sold in street markets in the capital, irrespective of their region of origin, reach their slaughter weight at an advanced age and with a lean body condition, resulting in carcasses of a low quality, with little muscle content, and insufficient fat cover.

In the extensive rearing conditions of the state of Ceará, sheep have the potential to produce more meat than goats.

\section{References}

ALCÂNTARA NETO, J. Análise da eficiência técnica da produção de ovinos e caprinos no município de TauáCeará. 2005. Dissertação (Mestrado em Economia) Universidade Federal do Ceará, Fortaleza.
ARAÚJO FILHO, J. A.; CARVALHO, F. C.; SILVA, N. L. Criação de ovinos a pasto no semiárido nordestino. Sobral: EMBRAPA-CNPC, 1999. 18 p. (EMBRAPACNPC. Circular técnica, 19).

ARAÚJOFILHO, J.A.; SILVA, N. L. Impacto do pastoreio de ovinos e caprinos sobre os recursos forrageiros do semiárido. In: SEMINÁRIO NORDESTINO DE PECUÁRIA, 4., Fortaleza, CE, Anais... Fortaleza, 2000, p. 11-18.

CARTAXO, F. Q.; SOUSA, W. H.; COSTA, R. G.; CEZAR, M. F., PEREIRA FILHO, J. M.; CUNHA, M. G. G. Características quantitativas da carcaça de cordeiros de diferentes genótipos submetidos a duas dietas. Revista Brasileira de Zootecnia, Viçosa, MG, v. 40, n. 10, p. 2220-2227, 2011.

CEZAR, M. F.; SOUSA, W. H. Avaliação e utilização da condição corporal como ferramenta de melhoria da reprodução e produção de ovinos e caprinos de corte. In: REUNIÃO ANUAL DA SOCIEDADE BRASILEIRA DE ZOOTECNIA, 43., João Pessoa, 2006. Anais... João Pessoa: SBZ, 2006. p. 649-678.

. Carcaças ovinas e caprinas: obtenção, avaliação e classificação. Uberaba: Agropecuária Tropical, 2007. $232 \mathrm{p}$.

COSTA, R. G.; ALMEIDA, C. C.; PIMENTA FILHO, E. C.; HOLANDA JUNIOR, E. V.; SANTOS, N. M. Caracterização do sistema de produção caprino e ovino na região semiárida do estado da Paraíba, Brasil. Revista Archivos de Zootecnia, Córdoba, v. 57, p. 195-205, 2008.

GUIMARÃES FILHO, C.; SOARES, J. G. G.; ARAÚJO, G. G. L. Sistemas de produção de carnes caprinas $e$ ovina no semiárido nordestino. In: SIMPÓSIO INTERNACIONAL SOBRE CAPRINOS E OVINOS DE CORTE, 1., 2000, João Pessoa, PB. Anais... João Pessoa: EMEPA-PB, 2000. p. 21-33.

INSTITUTO BRASILEIRO DE GEOGRAFIA E ESTATÍSTICA - IBGE. Efetivo dos rebanhos por tipo de rebanho. 2013. Disponível em: <http://www.sidra.ibge. gov.br>. Acesso em: 19 jan. 2013.

LANDIM, A. V.; MARIANTE, A. S.; McMANUS, C.; GUGEL, R.; PAIVA, S. R. Características quantitativas da carcaça, medidas morfométricas e suas correlações em diferentes genótipos de ovinos. Ciência Animal Brasileira, Goiânia, v. 8, n. 4, p. 665-676, 2007.

LEITE, E. R.; VASCONCELOS, V. R. Estratégias de alimentação de caprinos e ovinos em pastejo no Nordeste do Brasil. In: SIMPÓSIO INTERNACIONAL SOBRE CAPRINOS E OVINOS DE CORTE, 1., 2000, João Pessoa. Anais... João Pessoa: EMEPA-PB, 2000. p. 71-80. 
MADRUGA, M. S. Fatores que afetam a qualidade da carne caprina e ovina. In: SINCORTE - SIMPÓSIO INTERNACIONAL DE CAPRINOS E OVINOS DE CORTE, 2., 2003, João Pessoa, PB. Anais... João Pessoa: EMEPA, 2003. p. 417-432.

MADRUGA, M. S.; COSTA, R. G.; BESERRA, F. J. Carne caprina: uma alternativa para o Nordeste. In: SIMPÓSIO DE PRODUÇÃO ANIMAL DO NORDESTE, 1., 1999, Recife. Anais... Recife, 1999. p. 41-58.

MARTINS JÚNIOR, L. M.; RIBEIRO, D. M. M.; COSTA, A. P. R.; TURCO, S. H. N.; MURATORI, M. C. S. Respostas fisiológicas de caprinos Boer e AngloNubiana em condições climáticas de meio-norte do Brasil. Revista Caatinga, Mossoró, v. 20, n. 2, p. 1-7, 2007.

MARTINS, R. C.; OLIVEIRA, N.; OSORIO, J. C. S.; OSÓRIO, M. T. M. Peso vivo ao abate como indicador do peso e das características quantitativas e qualitativas das carcaças em ovinos jovens da raça Ideal. Bagé: EMBRAPA-CPPSUL, 2000. 29 p. (EMBRAPACPPSUL. Boletim de Pesquisa, 21).

NUNES, H.; ZANINE, A. M.; MACHADO, T. M. M.; CARVALHO, F. C. Alimentos alternativos na dieta dos ovinos. Asociación Latinoamericana de Producción Animal, Cusco, v. 15, p. 141-151, 2007.

OLIVEIRA, A. N.; SELAIVE-VILLARROEL, A. B.; MONTE, A. L. S.; COSTA, R. G.; COSTA, L. B. A. Características da carcaça de caprinos mestiços AngloNubiano, Boer e sem padrão racial definido. Ciência Rural, Santa Maria, v. 38, n. 4, p. 1073-1077, 2008.

OLIVEIRA, J. C. V.; ROCHA, L. L.; RIBEIRO, M. N.; GOMES FILHO, M. A. Caracterização e perfil genético visível de caprinos nativos no estado de Pernambuco. Revista Archivos de Zootecnia, Córdoba, v. 55, n. 209, p. 63-73, 2006.

PINHEIRO, R. S. B.; JORGE, A. M. Medidas biométricas obtidas in vivo e na carcaça de ovelhas de descarte em diferentes estágios fisiológicos. Revista Brasileira de Zootecnia, Viçosa, MG, v. 39, n. 2, p. 440-445, 2010.

SAÑUDO, C.; ALFONSO, M.; SÁNCHEZ, A.; DELFA, R.; TEIXEIRA, A. Carcass and meat quality in light lambs from different fat classes in the EU carcass classification system. Meat Science, Amsterdam, v. 56, p. 89-94, 2000.

SILVA SOBRINHO, A. G. Aspectos quantitativos $e$ qualitativos da produção de carne ovina. A produção animal na visão dos brasileiros. In: REUNIÃO ANUAL DA SOCIEDADE BRASILEIRA DE ZOOTECNIA, 38., 2001, Piracicaba, SP. Anais... Piracicaba: Sociedade Brasileira de Zootecnia, 2001a. p. 425-446.
Produção de cordeiros em pastagens. In: SIMPÓSIO MINEIRO DE OVINOCULTURA, 1., 2001, Lavras, MG. Anais... Lavras: UFLA, 2001b. p. 63-98.

SILVA SOBRINHO, A. G.; MORENO, G. M. B. Produção de carnes ovina e caprina e cortes da carcaça. In: SEMINÁRIO NORDESTINO DE PECUÁRIA, 13., 2009, Fortaleza. Anais... Fortaleza: Universidade Federal do Ceará, 2009. p. 1-37.

SILVA, F. L. R.; ARAÚJO, A. M. Desempenho produtivo de caprinos mestiços no semiárido do nordeste do Brasil. Revista Brasileira de Zootecnia, Viçosa, MG, v. 29, n. 4, p. 1028-1035, 2000.

SILVA, N. V.; COSTA, R. G.; FREITAS, C. R. G.; GALINDO, M. C. T.; SILVA, L. S. Alimentação de ovinos em regiões semiáridas do Brasil. Acta Veterinaria Brasilica, Mossoró, v. 4, n. 4, p. 233-241, 2010.

SIQUEIRA, E. R.; SIMÕES, C. D.; FERNANDES, S. Efeito do sexo e do peso ao abate sobre a produção de carne de cordeiro. I. Velocidade de crescimento, caracteres quantitativos da carcaça, $\mathrm{pH}$ da carne e resultado econômico. Revista Brasileira de Zootecnia, Viçosa, MG, v. 30, n. 3, p. 844-848, 2001.

SOUSA, W. H.; BRITO, E. A.; MEDEIROS, A. N.; CARTAXO, F. Q.; CEZAR, M. F.; CUNHA, M. G. G. Características morfométricas e de carcaça de cabritos e cordeiros terminados em confinamento. Revista Brasileira de Zootecnia, Viçosa, MG, v. 38, n. 7, p. 1340-1346, 2009.

SOUZA, B. B.; DANUSIO, S. E.; CEZAR, M. F.; SOUZA, W. H.; SANTOS, J. R. S.; BENICIO, T. M. A. Temperatura superficial e índice de tolerância ao calor de caprinos de diferentes grupos raciais no semiárido nordestino. Ciência Agrotécnica, Lavras, v. 32, n. 1, p. 275-280, 2008.

SUGUISAWA, L.; MATTOS, W. R. S.; OLIVEIRA, H. N.; SILVEIRA, A. C.; ARRIGONI, M. B.; SOUZA, A. A. Correlações simples entre as medidas de ultrassom e a composição da carcaça de bovinos jovens. Revista Brasileira de Zootecnia, Viçosa, MG, v. 35, n. 1, p. 169176, 2006.

YÁÑEZ, E. A.; RESENDE, K. T.; FERREIRA, A. C. D.; MEDEIROS, A. N.; SILVA SOBRINHO, A. G.; PEREIRA FILHO, J. M.; TEIXEIRA, I. A. M. A.; ARTONI, S. M. B. Utilização de medidas biométricas para predizer características da carcaça de cabritos Saanen. Revista Brasileira de Zootecnia, Viçosa, MG, v. 33, n. 6, p. 1564-1572, 2004.

ZAPATA, J. F. F.; SEABRA, L. M. A. J.; NOGUEIRA, C. M.; BEZERRA, L. C.; BESERRA, F. J. Características de carcaça de pequenos ruminantes do Nordeste do Brasil. Revista Ciência Animal, v. 11, n. 2, p. 79-86, 2001. 
